Pamiętnik Literacki 2016, 4, s. 79-94
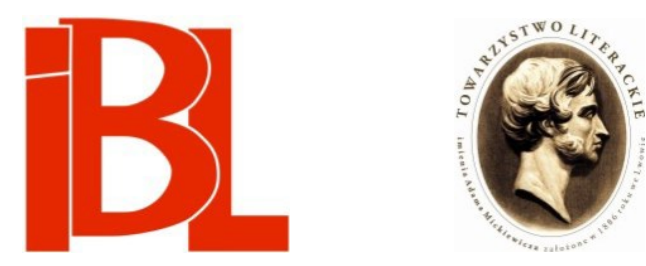

\title{
Topografia pamięci w „Tajemnicy lorda Singelworth" Norwida
}

Mateusz Grabowski 


\title{
TOPOGRAFIA PAMIĘCI W „TAJEMNICY LORDA SINGELWORTH” NORWIDA
}

\begin{abstract}
Pamięć pojęta jako pobożność odgrywa tutaj głęboko tajemniczą rolę. Nie tylko jedną z cech Jehowy, lecz wprost jego cechą najistotniejsza jest to, że zachowuje on niezawodną pamięć „do trzeciego i czwartego”, ba, do „setnego pokolenia”; najświętszym aktem rytuału jest wymazanie grzechów $z$ księgi pamięci ${ }^{1}$.
\end{abstract}

Cyprian Norwid, pisząc cykl nowel włoskich, przypuszczał, że środki zdobyte dzięki ich publikacji pozwolą mu na upragniony powrót do Italii, tym samym zaś na podreperowanie zdrowia, zniszczonego gruźlica, i rozpoczęcie nowego etapu w życiu i twórczości. Poeta marzył o spokojnym pobycie w Nicei, gdzie stałym źródłem zarobku byłyby udzielane przez niego lekcje akwareli. Stąd też jego ostatnie nowele wydają się przesiąknięte tęsknotą, a pieczołowicie odmalowana w nich topografia włoskich miast: Bagni di Lucca, Rzymu i Wenecji, jawi się jako nasycone niezwykła intymnością ślady pamięci. W każdym $\mathrm{z}$ tych tekstów wybrzmiewa nakaz pamięci. W Stygmacie okazuje się ona nośnikiem traumy, która jest piętnem trwale znaczącym charaktery bohaterów. Przymus pamiętania o męczennikach w utworze „Ad leones!" zostaje skonfrontowany z przemoca generowana przez mechanizmy wolnego rynku. Dłuto głównego bohatera, zamiast oddawać prawdę dziejów, próbuje wyżłobić ją na nowo, zmieniając sztukę w groteskowy fantazmat. W Tajemnicy lorda Singelworth cały swiat przedstawiony stanowi wcielenie powracajaccej przeszłości - zarówno tej chwalebnej, jak i tej bolesnej, skazanej na zapomnienie, pogrzebanej pod ulicami, w pokładach brudu i błota. W ostatnim utworze, będącym podsumowaniem cyklu włoskiego, odniesienia do historii i historyczności decydują o konstrukcji świata przedstawionego. Norwidowska Wenecja jest miejscem spotkania przeszłości z teraźniejszością. Wszystkie zabytki, ulice, pomniki - cała topografia miasta prezentuje intymny krajobraz wspomnień poety.

Wielka historia w nowelach włoskich, a szczególnie w Tajemnicy lorda Singelworth, zyskuje wymiar prywatności. Przenika życie bohaterów, wpływając na ich tożsamość. Ostatnia $z$ nowel włoskich pozwala czytelnikowi nie tylko zanurzyć się w przeszłości. Refleksja historyczna stanowi część głębszych rozważań poety nad

1 W. Hass, Gestalten der Zeit. Berlin 1930. Cyt. za: W. B en ja min, Franz Kafka. Z okazji dziesiatej rocznicy jego śmierci. W zb.: Nienasycenie. Filozofowie o Kafce. Red. Ł. M u siał, A. Ż ychliński. Kraków 2011, s. 47 (przeł. A. Lipszyc). 
kondycją kultury i cywilizacji europejskiej drugiej połowy XIX wieku. Jak bowiem stwierdziła Alicja Lisiecka:

Gdyby w literaturze dwudziestowiecznej szukać przedłużenia linii, którą reprezentowała twórczość Norwida w wieku XIX, trzeba byłoby zwrócić się nie do polskiej awangardy poetyckiej i nie do polskiego klasycyzmu, ale do Eliota i Valéry'ego. Do poetów historii i do poetów refleksji. Do poetów kultury i poetów synkretyzmu stylistycznego ${ }^{2}$.

Namysł nad dziejami podporządkował Norwid analizie współczesności. W historii poeta poszukiwał mianowicie mechanizmów rządzących teraźniejszością drugiej połowy XIX stulecia ${ }^{3}$ - epoki, która w tej pracy jest rozumiana jako początek tzw. późnej nowoczesności ${ }^{4}$. To problem wymagający głębszego rozpatrzenia, niemniej warto zastanowić się, czy refleksja historiozoficzna autora Promethidiona nie koncentruje się również na dociekaniu źródeł „wieku kupieckiego” (do którego poeta miał stosunek wyraźnie dwuznaczny ${ }^{5}$ ) oraz - w szerszej perspektywie - nowoczesności, szczególnie w jej dalszej fazie ${ }^{6}$. Norwid, jak zauważa Sławomir Rzep-

2 A. Lis i e cka, Norwid. Poeta historii. London 1973, s. 11.

3 Problem stosunku Norwida do nowoczesności, jak zauważył S. Rzepczyński (Norwid a nowoczesność. W zb.: Romantyzm i nowoczesność. Red. M. Kuzia k. Kraków 2009), wymaga osobnej rozprawy. Jak dotąd pojawiło się kilka prac, których celem było ukazanie relacji między autorem Vade-mecum a różnorodnie rozumianą nowoczesnością: Z. S t e f a n o w s k a, Pisarz wieku kupieckiego i przemysłowego. W zb.: Literatura, komparatystyka, folklor. Księga poświęcona Julianowi Krzyżanowskiemu. Red. M. Bokszczanin, S. Frybes, E. Jankowski. Warszawa 1968 (przedr. w: Z. Ste fa n ow s ka, Strona romantyków. Studia o Norwidzie. Lublin 1993). Li s i e cka, op. cit. - E. Bi eń k ow s ka, Dwie twarze losu. Nietzsche-Norwid. Warszawa 1975. - A. van Ni e uk erken, Ironiczny konceptyzm. Nowoczesna polska poezja metafizyczna $w$ kontekście anglosaskiego modernizmu. Kraków 1998. - W. Rzoń ca, Norwid a romantyzm polski. Warszawa 2005.

4 Pojęcie późnej nowoczesności przejmuję od A. Giddens a (Nowoczesność i tożsamość. „Ja” i społeczeństwo w epoce późnej nowoczesności. Przeł. A. Szulży c k a. Wyd. 2. Warszawa 2010). Autor stawia tezę, że początek tej fazy nowoczesności należy datować na przełom XIX i XX wieku, niemniej pierwsze sygnały jej nadejścia, takie jak postępująca globalizacja ekonomiczna i kulturowa oraz powstawanie coraz bardziej skomplikowanych mechanizmów organizacyjnych, każą widzieć jej narodziny już w połowie XIX stulecia. Dlatego najbardziej poręcznym instrumentarium teoretycznym w analizie późnej nowoczesności, poza pracą Giddensa, wydają się też tezy Th. Adorna i M. Horkheimera (narodziny „przemysłu kulturalnego”) oraz W. Benjamina (proces „haussmannizacji”, powstanie wielkich domów towarowych w Paryżu).

5 Zob. Stefanowska, op. cit., s. 29-30.

6 Ciekawa wydaje się analiza pod tym kątem dwóch późnych tragedii C. Norwida - Pierścienia Wielkiej-Damy, czyli ex-machina Durejko oraz Kleopatry i Cezara. Bohaterów białej tragedii z bohaterami tragedii historycznej łączy dekadentyzm. Co więcej, istnieją podobieństwa sytuacyjne w akcji wymienionych dramatów (ostatni akt Pierścienia Wielkiej-Damy i I akt Kleopatry i Cezara). Na pogłębioną refleksję zasługuje jednak przede wszystkim różnica gatunkowa, jaka zachodzi pomiędzy tymi utworami. Pisząc białą tragedię, Norwid rezygnuje z - właściwej sztukom historycznym: Kleopatrze i Cezarowi, a także wcześniejszym: Wandzie (1852) i Krakusowi (1861) misteryjności, sprzyjającej rozważaniom nad mechanizmami dziejowymi. Przesilenie kultur antycznych w Kleopatrze i Cezarze podporządkowane jest określonej refleksji historiozoficznej; reprezentanci starożytnych cywilizacji podlegają ewolucji historycznej, kulturowej i metafizycznej. Bohaterowie Pierścienia Wielkiej-Damy natomiast wydają się wydziedziczeni z historii, a tym samym pozbawieni własnej tożsamości. Uniwersum białej tragedii bliskie jest współczesności - Eliotowskiej ziemi jałowej, której mieszkańcy zapomnieli o przeszłości, by trwać w martwej teraźniejszości, nieskończonym „tu i teraz” - piekle rzeczywistości, jakiemu nie ma końca. 
czyński, był twórcą należącym do rodzącej się nowoczesności, skupionym na jej mechanizmach i materialnych przejawach jej ewolucji ${ }^{7}$.

Podstawowy problem tej rozprawy wiąże się z zagadnieniem relacji między przeszłością a teraźniejszością w Tajemnicy lorda Singelworth. Autor, oprowadzając czytelników po współczesnej mu Wenecji, zabiera ich w podróż, gdzie to, co przeszłe, stanowi trwały element status quo. Bohaterowie utworu staja się tym samym świadkami historii. To właśnie imperatyw pamięci, który stygmatyzuje wszystkie zabytki Norwidowskiej Wenecji, prowadzi ich ku zrozumieniu coraz bardziej wymykającej się im teraźniejszości. Pamięć jawi się Norwidowi jedynym ratunkiem przed zbliżającą się katastrofą współczesności:

Można by rzec, że tym, co stanowi o oryginalności jego poezji, jest w dużej mierze własna koncepcja kulturowej pamięci, jej miejsce i rola, jaką może pełnić w twórczości „pisarza wieku kupieckiego i przemysłowego" 8 .

Norwid postanowił uczynić Wenecję miejscem akcji w noweli będącej podsumowaniem jego poglądów historycznych i historiozoficznych, dlatego że - w przeciwieństwie do Paryża, zburzonego i odbudowanego przez Georges'a-Eugène’a Haussmanna - zachowywała ona pamięć minionych dziejów. Okazała się idealną przestrzenią do zaistnienia tajemnicy, której rozwiązanie pozwoli zrozumieć teraźniejszość oraz poznać kształt nadchodzącej przyszłości.

\section{Topografia pamięci}

Rozróżniając pamięć i historię, odwołuję się do badań prowadzonych przez Maurice’a Halbwachsa i jego kontynuatora Jana Assmanna. Według Halbwachsa (cytuję za Assmannem) relacja między historią a pamięcią -

jest [...] stosunkiem następstwa. Tam, gdzie nie pamięta się już, czyli nie przeżywa przeszłości, miejsce pamięci zajmuje historia. [...] Domena historyka to przeszłość „niezamieszkana”, która nie należy już do pamięci zbiorowej ${ }^{9}$.

Pamięć zbiorowa, sądzi autor La Topographie légendaire des Évangiles en Terre Sainte, magazynuje w sobie elementy właściwe pamięci komunikatywnej i kulturowej. Zdaniem Assmanna natomiast we współczesnej nam Europie pamięć komunikatywna, której domeną jest przekaz ustny, obejmuje jedynie trzy, a nawet cztery pokolenia. Pamięć kulturowa zaś przekracza zakres komunikatywnej, sięga znacznie dalej, bo aż do prahistorii zapoczątkowanej przez mit założycielski. Poprzez odniesienie do sfery mitycznej, buduje nie tylko tożsamość jednostki, ale również całego społeczeństwa:

Rze pczyński, op. cit., s. 185.

K. Try b u ś, Pamięć romantyzmu. Studia nie tylko z przeszłości. Poznań 2011, s. 178.

J. A s s m a n n, Pamięć kulturowa. Pismo, zapamiętywanie i polityczna tożsamość w cywilizacjach starożytnych. Przeł. A. Kry c zy ńs ka - P h a m. Wstęp, red. nauk. R. Tr a ba. Wyd. 2. Warszawa 2015, s. 60. Pomiędzy obszarami prahistorii a historii najnowszej istnieje tzw. floating gap przestrzeń wydarzeń, które umykaja pamięci, nie mogą bowiem być już przekazane ustnie ani nie są częścią mitu konstytuującego teraźniejszość. Zob. też s. 64-70. 
Chodzi o zjawisko pamiętania, które wyraża się świadomym stosunkiem grupy do przeszłości osadzonej w konkretnej przestrzeni kulturowej, przekazywanej poprzez różne formy komunikacji społecznej: pismo, obraz, święta, rytuały itp. W przeciwieństwie do nieformalnej i mało zrestrukturyzowanej pamięci komunikatywnej pamięć kulturowa wyróżnia się bardziej sakralnym, symbolicznym czy wręcz abstrakcyjnym charakterem, co sprawia, że jej kreatorami nie mogą już być poszczególne jednostki, ich rolę przejąc muszą zorganizowane instytucje ${ }^{10}$.

Według Assmanna pamięć i historia są kreowane przez zorganizowane instytucje społeczne i kulturowe. Stanowią one element strategii kulturowej pozwalajacej danej społeczności na samookreślenie się. Podobnie definiował pamięć zbiorową Halbwachs, uznając ją za żywioł budujący i konstytuujący tożsamość kulturowa. Doświadczenie pamięci zbiorowej powinno być więc w pełni uświadomione. Wykorzystuje ona bowiem język symboli, który dana społeczność rozumie i potrafi dekodować. Pamięć zbiorowa ma zatem charakter mimowolny (mémoire volontaire), inaczej niż jungowska pamięć wolicjonalna (mémoire involontaire) ${ }^{11}$. Uświadomienie doświadczenia pamięci zbiorowej prowadzi według Halbwachsa do jej zobiektywizowania i tym samym do włączenia się jej w szerszą strategię kulturową, której najbardziej widocznym przejawem jest tradycja. Halbwachs - inaczej niż jego kontynuator - sprzeciwiał się obiektywizacji pamięci, zawłaszczeniu jej przez zorganizowane instytucje społeczne i kulturowe. Tradycja była dla niego zniekształceniem pamięci ${ }^{12}$. Na potrzeby wywodu poświęconego analizie roli pamięci w Tajemnicy lorda Singelworth postanowiłem przyjąć stanowisko Assmanna, które uznaję za bardziej funkcjonalne i użyteczne:

Przejścia między mémoire i tradition bywają tak płynne, że wprowadzenie zbyt ostrych rozróżnień pojęciowych nie wydaje się sensowne. Dlatego my używamy pojęcia pamięci (zbiorowej) jako nadrzędnego, a w jego ramach rozróżniamy pamięć komunikatywną i kulturową ${ }^{13}$.

Topografia pamięci w ostatniej noweli Norwida zanurzona jest w pamięci zbiorowej, opierającej się na pamięci komunikatywnej - historii jego przyjaźni z malarzem Tytusem Byczkowskim - oraz na pamięci kulturowej, która odbiła się refleksem na budynkach starodawnej Wenecji. Wcielenie wielkiej historii poprzez pamięć kulturową w topografię miasta dożów uznaję za proces semiotyzacji przestrzeni:

Sztuka pamięci posługuje się przestrzenią wyobrażoną, a kultura pamięci rozmieszcza swe znaki w przestrzeni naturalnej. Nawet całe krajobrazy - i szczególnie krajobrazy - służą jako medium pamięci kulturowej; nie przez umieszczanie w nich znaków (,pomników”), lecz przez podniesienie całości do rangi znaku, czyli przez s e mi otyza cję ${ }^{14}$.

Semiotyzacja przestrzeni, jak słusznie zauważa Krzysztof Trybuś, stanowi podstawowy sposób konstrukcji świata przedstawionego w twórczości autora Vade-mecum:

Ibidem, s. 15

11 Tłumaczenie terminów przyjmuję za R. Mi chals kim (W poszukiwaniu „rajskich imion” - antropologia filozoficzna wobec problemu genezy języka. „Filo-Sofija” 2006, nr 6, s. 106). 
Liryki Norwida, jak i większe utwory narracyjne, sa zbudowane konsekwentnie wokół tematów przestrzennych, co wielokrotnie opisywano. Warto w tej tematyzacji przestrzeni odnaleźć także funkcję upamiętniania kulturowej przeszłości. Podniesiona do rangi znaku przestrzeń Rzymu jest w literaturze europejskiej krajobrazem pamięci, topograficznym tekstem pamięci kulturowej. Łączenie wyobrażeń z miejscem to - jak wiadomo - kanon zachodniej sztuki pamiętania. Już w czasach antycznych Rzym był rodzajem świętego krajobrazu ${ }^{15}$.

Kręte uliczki i meandryczne szlaki weneckich kanałów, antyczne pomniki, których historia sięga czasów potęgi kultury bizantyjskiej, zmurszałe i rozpadające się zabytki - każdy z tych detali, tak pieczołowicie odmalowany przez Norwida w Tajemnicy lorda Singelworth, staje się znakiem pamięci. Elementami topografii pamięci sa ,wszystkie znane sposoby wykorzystywane przez grupy ludzi, nie tylko Kościoły, ale również przez inne wspólnoty, rodziny, narody itd., których celem jest organizacja ich wspomnień dotyczących miejsc, ale także czasu, zdarzeń, ludzi" ${ }^{16}$.

Topografia, spleciona $z$ nakładających się na siebie sieci wspomnień, roztacza horyzont wybiegający daleko poza śódziemnomorską lagunę. Tę granicę wyznacza przestrzeń mitu, legendy - przestrzeń słowa. To właśnie tkanie słowem (rozumianym również w sensie ewangelicznym) stało się dla Norwida podstawowym sposobem organizacji pamięci.

\section{Flâneur w balonowym koszu}

Wenecka przygoda lorda Singelworth zaczęła się w słynnym hotelu Pod Białym Lwem, gdzie bohater postanowił się zatrzymać. Hotel ten założony został w wieku XVI, ale sam budynek pochodzi z XIII stulecia. Położony nad brzegiem Wielkiego Kanału, między pałacem Ca' d'Oro a mostem Rialto, czyli w samym sercu miasta, był niejednokrotnie areną wielkiej historii ${ }^{17}$. Stamtąd Lord wybrał się na wyspę Lido - punkt, $z$ którego miał odbyć swój pierwszy wenecki lot balonem. Hotel oraz wyspa to kluczowe miejsca wyznaczające Norwidowską topografię pamięci.

Na 33 lata przed napisaniem Tajemnicy lorda Singelworth Norwid przygotował krótki tekst o niemal reportażowym charakterze, zatytułowany Menego, przedstawiający ostatni dzień spędzony w Wenecji z Tytusem Byczkowskim. W tej szczegółowej relacji chciał prawdopodobnie zrozumieć tragedie przyjaciela. Norwid był

Trybuś, op. cit., s. 182.

M. Halbw a chs, La Topographie légendaire des Évangiles en Terre Sainte. Étude de mémoire collective. Éd. preparée par M. Jais s on, avec les contributions de D. Hervieu-Léger, J.-P. Cléro, S. Gensburger, É. Brian. Paris 2008, s. 147. Autor rozróżnia i niuansuje sposób wykorzystania pamięci w rozmaitych organizacjach społecznych, szczególnie zwracając uwage na modele pamięci zbiorowej funkcjonujące w rodzinach oraz grupach religijnych. Zob. M. Ha lbw a c h s, Społeczne ramy pamięci. Przekł., wstęp M. Król. Warszawa 1969, s. 217-323. Hotel ten gościł licznych władców europejskich podczas ich wizyt w Wenecji, np. cesarza Austrii Józefa II, który - być może - polecił nocleg w tym szacownym miejscu wielkiemu księciu Pawłowi Piotrowiczowi, gdy jako następca rosyjskiego tronu podróżował on po Europie zimą 1786. Carewicz już pierwszego dnia pobytu wziął udział wraz z najwyższymi dostojnikami miasta w oficjalnym obiedzie w Teatrze San Benedetto. Uroczystość została uwieczniona na ostatnim obrazie włoskiego malarza G. Bellego. 
ostatnią osobą, z którą Byczkowski skontaktował się przed odebraniem sobie życia (autor przytacza jego oryginalny, ostatni list; według Juliusza Wiktora Gomulickiego dokument ów jest „bez watpienia autentyczny” $\langle\mathrm{N}-7547\rangle^{18}$ ). Tytułowe „me-nego”, oznaczające „topię się”, stanowi próbę określenia tragicznego losu. Z jednej strony, określenia dosłownego (Byczkowski popełnił samobójstwo, podcinając sobie gardło i zanurzając się w odmętach zatoki morza ${ }^{19}$ ), a z drugiej - symbolicznego, Menego jest bowiem przede wszystkim portretem człowieka pogrążającego się w depresji i skazanego na samozagładę. Historia śmierci Byczkowskiego wpisuje się w przestrzeń topografii pamięci, ukształtowanej przez ciążące nad Wenecją fatum samobójczej śmierci ${ }^{20}$.

Ukazuje to improwizacja bohatera Tajemnicy lorda Singelworth, weneckiego artysty - Tony’ego di Bona Grazii. Według Elżbiety Dąbrowicz jego wypowiedź ma wyraźnie zarysowaną kompozycję. Jej punkt zwrotny stanowi wzmianka o samobójstwach w Wenecji. Wcześniejsza ironiczna kpina, wymierzona przeciwko europejskiej opinii publicznej, śledzącej wszystkie poczynania tajemniczego lorda, przechodzi w pełen współczucia tragizm, gdy mówiący porusza temat weneckich samobójców. Dąbrowicz zauważyła, że niemal groteskowa teatralność „publicznego improwizatora" i wielość środków aktorskich, jakimi się on posługuje (częste zmiany akcentów, gestykulacja, strój arlekina), służą maksymalnemu zdystansowaniu się wobec opresji społecznej. Ironia artysty uderza w obce władze okupujace miasto ${ }^{21}$ oraz w tyranię vox populi.

Celem monologu arlekina była jednak nie tylko obrona, lecz również zdemaskowanie lorda. Artysta stawiał sobie i swym słuchaczom pytanie o to, jaki cel miały tajemnicze wyprawy arystokraty. Wydaje się, że główny bohater noweli Norwida, pochłonięty realizacja puryfikacyjnej misji, ignoruje piękno Wenecji - zawieszony w balonowym koszu, nie może podziwiać zachwycającej architektury miasta:

Starożytne gmachy, np. więzień naszych: Piombi lub Most - we s t c h nień, z góry widziane, podobno, iż wydają się oku jak pełzające płaskie robactwo; ale nie myślę, ażeby cztery konie Świętego Marka, kiedy zarżą płucami złotymi i zachwieją grzywami z korynckiego brązu w słońca blasku, widokiem były obojętnym! Tego jednak, z wysokości wielkiej nie baczy się - jest znikający w masach ciemny wyjątek!... Lecz nie należałożby właściwiej podzielić i uzasadnić mniemanie, iż powietrzny la ta wi e c ma jedną $z$ tych głębokich historycznych tajemnic, które się dopiero po wiekach wyjaśniają? [N-6 $150-151]$

Di Bona Grazia podziela Baudelaire’owską obawę przed obojętnością, sprawiającą, że wzrok stracił zdolność spoglądania ${ }^{22}$. Jak zauważył Walter Benjamin,

Skrótem tym oznaczam odwołania do dzieł C. N o r wi d a cytowanych za wydaniem: Pisma wszystkie. Zebrał, tekst ustalił, wstępem i uwagami krytycznymi opatrzył J. W. G o m uli cki. T. 1-11. Warszawa 1971-1976. Pierwsza liczba po łączniku wskazuje numer tomu, a druga - stronicy. Okoliczności samobójstwa Byczkowskiego przedstawia raport sporządzony przez wenecką policję. Zob. Z. Troja now i z zow a, Z. D a m b ek, przy współudz. J. Czarno mors ki ej, Kalendarz życia i twórczości Cypriana Norwida. T. 1: 1821-1860. Poznań 2007, s. 140.

20 Zob. E. D ą b r ow i c z, „Tajemnica lorda Singelworth” Cypriana Norwida - strategia publicznego mówienia. „Studia Norwidiana” nr 3/4 (1985/1986), s. 224.

21 Zob. ibidem.

22 Zob. W. Benja min, O kilku motywach u Baudelaire'a. W: Konstelacje. Wybór tekstów. Przeł. A. Lipszyc, A. W ołkowicz. Wstęp A. Lipszyc. Kraków 2012, s. 305 (przeł. A. Li p szy c). 
fundamentem Kwiatów zła jest pragnienie przywrócenia umiejętności doświadczania:

Tylko dlatego, że Baudelaire przyswoił sobie te elementy [kulturowe, zawierające się w koncepcji doświadczenia], potrafił wymierzyć pełne znaczenie rozpadu, którego świadkiem był jako człowiek nowoczesny. Tylko dzięki temu mógł rozpoznać ów rozpad jako jemu właśnie pisane wyzwanie, które podją w Kwiatach zła. Jeśli rzeczywiście istnieje sekretna architektonika tego dzieła, której poświęcono mnóstwo spekulacji, to cykl wierszy otwierający cały tom byłby poświęcony czemuś, co bezpowrotnie utracone ${ }^{23}$.

W poezji Baudelaire’a często pojawia się obraz oczu, „o których chciałoby się powiedzieć, że zagubiły zdolność spoglądania" ${ }^{24}$. Wielkomiejski flâneur wydaje się skazany na poszukiwanie w ulicznym tłumie spojrzenia odwzajemniającego jego - poety, artysty, dandysa - zachwyt. Musi jednak odejść z niczym - spojrzenie pozostaje nieodwzajemnione, przechodnie otaczający flâneura pozbawieni są bowiem umiejętności doświadczania oczarowania estetycznego. Wygląda więc na to, że lord, zawieszony w balonowym koszu, podobnie pozostaje obojętny, „nieczuły estetycznie” (N-6 150) na piękno Wenecji oraz zdeponowanej w niej historii. Niemniej, jak zauważa improwizator, ,aeronaucja” pozwala arystokracie spojrzeć na Wenecję $z$ takiej pozycji, z której nie uczynił tego wcześniej żaden inny turysta. Dlatego loty Singelwortha określił di Bona Grazia mianem „głębokich historycznych tajemnic”. Artysta dostrzega, że w postawie lorda jest coś, co zasługuje na duży szacunek. Żeby zrozumieć tę konstatację, warto powrócić do Wenecji takiej, jaką opisuje improwizator.

Wspominając to miasto, skupiając się na jego przeszłości, di Bona Grazia mówi przeważnie o przestrzeniach, na których odbiła się trauma historyczna. Wymieniane przez niego zabytki to: Piombi, Most Westchnień oraz posag czterech koni znajdujący się nad wejściem do Bazyliki św. Marka. Nazwę Piombi nosi dawne więzienie w Pałacu Dożów, a Most Westchnień (Ponte dei Sospiri) to obudowany ze wszystkich stron korytarz łączący ów pałac z głównym budynkiem więziennym, tzw. Prigioni, wybudowanym w 1589 roku. Cztery konie św. Marka stanowia domniemane dzieło słynnego greckiego rzeźbiarza Lizyppa, ozdabiające niegdyś wielki hipodrom w Bizancjum. Posag przewieziono w 1205 roku do Wenecji i ulokowano ponad głównym wejściem do bazyliki. Znajduje się on tam do dziś ${ }^{25}, z$ wyjątkiem krótkiego - lecz znamiennego dla interpretowanej tu improwizowanej przemowy okresu kilkunastu lat. W roku 1797 pomnik został zabrany przez Napoleona do Paryża, by 18 lat później powrócić do Wenecji. Strata legendarnego dzieła, uchodzącego za symbol Republiki Weneckiej, dopełniła upadek państwa. W monologu di Bona Grazii przestrzeń traumy historycznej rozciaga się na wszystkie weneckie zabytki:

Wprawdzie [...], ażeby starożytną lub ubiegłą zachwycać się swobodnie tryumfalnością, należałoby usilnie zapomnieć, iż z tych gotyckich wież, z tych tryumfalnych łuków i kolumn, tego rana, wczora 
i w różne onegdaje, zrzucali się rozpacza gnani śmiertelnicy nieszczęśni, i podobno że oni zrzucać się dziś jeszcze zamyślają lub będa jutro. Atoli i przez takowy deszcz krwi i łez patrząc na architekturę piękną, można nie być nieczułym estetycznie!... [N-6 150]

Norwid, pisząc w Tajemnicy lorda Singelworth o przeszłości, konsekwentnie stosuje technikę przybliżenia, której celem jest rekonstrukcja pamięci. Tytułowy bohater zaczyna swą wenecką podróż od wielkiej historii, symbolizowanej przez budynek hotelu Pod Białym Lwem, by później udać się na wyspę Lido - miejsce śmierci Byczkowskiego. Improwizujący di Bona Grazia prezentuje dzieje Wenecji, przechodząc od opisu wielowiekowego piękna zabytków do indywidualnych tragedii samobójców. Jak zauważył Trybuś:

Posługując się rozróżnieniami Assmanna, można by rzec, że wyobraźnia poetycka Norwida porusza się nieustannie pomiędzy pamięcią fundacyjną emigracyjnej wspólnoty, sięgającą do czasu jej początków, a pamięcią biograficzną, odnoszącą się do własnych doświadczeń życia. Wyobraźnię tę kształtują figury pamięci, które moderują włączanie obrazów $\mathrm{z}$ dawnego czasu w horyzont teraźniejszości, poddając tym samym pamiętaną przeszłość ciągłej rekonstrukcji26.

Interesująca wydaje się konstatacja badacza, według którego trzeba „czytać poezję Norwida jako zapis nieustającej rekonstrukcji różnej pamięci [...]"27. Takie odtworzenie pamięci ma jednak wymiar nie tylko etyczny, lecz - co ciekawe - również estetyczny.

Norwid, komentując monolog di Bona Grazii, stwierdza, że odbiorca, jakkolwiek świadom tragedii, jaka dotknęła weneckich samobójców, nie może „pozostać nieczułym estetycznie”. Doświadczenie estetyczne staje się jednocześnie doświadczeniem etycznym:

Bo piękno na to jest, by zachwycało

Do pracy - praca, by się zmartwychwstało. [N-3 440]

W architekturze Wenecji u Norwida, podobnie jak w Mickiewiczowskim Petersburgu, estetyka zmienia się w szyfr, którego rozwikłanie pozwala przywrócić pamięć ofiar:

W Dziadach, napisanych dla uczczenia „św. pamięci narodowej sprawy męczenników”, historię Polski zastapiła pamięć świadków i ofiar, a historię Rosji pomnik okrutnego władcy - metonimiczne przedstawienie doświadczenia przemocy. Ten rys monumentu jako formy pamięci o życiu narodu czytelny jest także w architekturze imperialnej stolicy, przechowującej w sobie pamięć ofiar ${ }^{28}$.

Według Norwida odbiór dzieła sztuki nie mógł być podporządkowany tylko przeżyciu zmysłowemu. Kontakt $z$ dziełem - a co za tym idzie, $z$ jego historią - powinien mieć również charakter duchowy, na co poeta wskazał m.in. w utworze Krytycy $i$ artyści:

co do sztuki pojęcia, której szeroko tu traktować nie jest czas ani miejsce - powiem tylko wyłącznie do publiczności polskiej, zwłaszcza tej, która estetyką rada się już zatrudnia - że czas by też zaprawdę

28 Ibidem, s. 63. 
z tego bez-żywotnego, bo nieprawdziwego, wyjść pojęcia, jakoby sztuka być powinna jakąś nad-zmysłową ekstatyczka! Tak nie jest, tak nie będzie, tak było, ale było, kiedy sztuką nie było to, co sztuką zowiemy. Albowiem sztuka jest, i owszem, uduchowioną zmysłowością, przez miłości wielkiej cało-dramat. [N-6 596]

Tym, co pozwala na świadomy odbiór piękna zdeponowanego w zabytkowej architekturze, jest uprzytomnienie sobie i doświadczenie historii. Imperatyw pamięci - według Grażyny Halkiewicz-Sojak, analizującej Norwidowski wiersz Historyk - stanowi fundament snutej przez autora Quidama refleksji o historii i archeologii:

Celem archeologii powinno być zatem poznanie człowieka, jego emocji i duchowej głębi. To zadanie wymaga jednak nie tylko wykopania z ziemi materialnych śladów dawnego życia, ale i ich hermeneutycznej lektury. I tu pojawia się pomost między poznaniem naukowym a poetyckim, między syntezą obu tych perspektyw a filozofią i antropologią ${ }^{29}$.

Zabłąkane spojrzenie flâneura może więc zostać odwzajemnione dzięki nałożeniu na plan miasta mapy topografii pamięci. Di Bona Grazia odkrywa bowiem, że celem aeronautycznych podróży lorda nie jest zdystansowanie się wobec historii, ale głębsze poznanie jej najbardziej ponurego oblicza. Singelworth, podziwiajac z góry zabytki i starodawną architekturę, patrzy z tej samej perspektywy, z jakiej widzieć je mogli ci, którzy chwilę później odebrali sobie życie ${ }^{30}$. Zamierzeniem lotów lorda okazuje się realizacja imperatywu pamięci o tych, których zmiażdżyło „parcie chemiczne Europy" (N-5 219).

\section{Terror rozumu instrumentalnego}

Tony di Bona Grazia jest wśród komentatorów wymienionych w noweli jedynym, któremu udało się odgadnąć prawdę i zrozumieć cel misji arystokraty. W utworze niemal cała Europa drugiej połowy XIX wieku szukała odpowiedzi na pytanie o to, co lord robi zawieszony w balonowym koszu nad różnymi stolicami Starego Kontynentu. Norwid prezentuje trzy stanowiska przedstawicieli opinii publicznej - francuskiego felietonisty, gubernatora Odessy oraz profesora $z$ Heidelbergu - i konfrontuje ich spostrzeżenia $z$ refleksją weneckiego improwizatora. Według paryskiego publicysty w balonie lord czyni ,jedynie starania około higieny osobistej” (N-6 148). Niewykluczone więc, że ekstrawagancja Singelwortha ma podłoże fizjologiczne. Sam tytuł noweli wiąże się przecież z tajemnicą arystokracji „surowo strzegącej swoich przywilejów i czystości krwi” ${ }^{31}$. Koncentracja na aspekcie higienicznym i fizjolo-

G. Halki e w i c z-S o j a k, Historiozof, historiograf czy miłośnik archeologii?-Norwidowski podmiot wobec tajemnicy dziejów. W zb.: Norwid wobec historii. Red. E. Chle b ow s ka, Ł. Ni ew czas. Lublin 2014, s. 45.

30 K. Trybuśs (Stary poeta. Studia o Norwidzie. Poznań 2000, s. 190-191) porównuje w dwóch Norwidowskich utworach poświęconych Wenecji: Menego i Tajemnicy lorda Singelworth, ich malarskość, przejawiającą się w technice opisu miasta. W Menego Byczkowski i Norwid „oglądają Wenecję niejako od środka, oglądają, jak powiada narrator, "szczegółowo". W Tajemnicy lorda Singelworth spotykamy się z innym spojrzeniem, zmierzającym do ogarnięcia całości tego dziwnego zjawiska, jakim jest Wenecja. Takiemu spojrzeniu sprzyja perspektywa balonowych lotów".

31 M. Ad a m i e c, Tajemnica lorda Singelworth, albo metafizyka balonu. „Studia Norwidiana” nr 3/4 (1985/1986), s. 202. 
gicznym idzie w parze $z$ fascynacją naturalizmem - filozofią, której przesyt zrodził pod koniec XIX wieku postawy dekadenckie. Możliwe, że postać słynnego felietonisty stanowi aluzję do samego Émile’a Zoli, gdyż według niego nawet za najbardziej wyrafinowaną tajemnicą kryć się muszą pobudki biologiczne.

Cesarstwo rosyjskie nie bez powodu reprezentuje urzędnik - trybik rozrośniętej do monstrualnych rozmiarów carskiej biurokracji. Gubernator Kutasów (jako jedyny $z$ wymienionych komentatorów obdarzony nazwiskiem - i to niezwykle sugestywnym...) podejrzewa lorda o przygotowywanie spisku, zapewne uważajacc arystokratę za anarchistę lub, co gorsza, zmartwychwstałego narodowolca, który planuje zamach. Jednak dzięki tyleż drobiazgowemu, co komicznemu śledztwu gubernator zrozumiał, że działania Singelwortha były tylko niewinną błahostką. Odeska przygoda lorda ukazała prawdziwe oblicze autorytarnego terroru. Trzeci komentator, niemiecki profesor $z$ Heidelbergu - pozytywistyczny scjentysta - przypuszczał natomiast, iż w trakcie lotów balonem lord dokonuje pomiarów meteorologicznych.

W ostatniej noweli włoskiej Norwid nakreślił obraz społeczeństwa europejskiego, którego istota jest pragnienie nieograniczonego kontrolowania swoich obywateli. Pragnienie to przejawia się w rozmaity sposób. Najlepszym narzędziem nadzoru staje się inwigilacja albo przez członków tej samej społeczności, albo przez aparat państwa. Tam, gdzie nie dotrze opresja władzy autorytarnej (jakiej ówcześnie podlegała również Wenecja, co Norwid kilkakrotnie zaznacza w noweli), nadzór przejmuje opinia publiczna, dysponująca potężną bronią - plotką - i tłumiąca wszelkie objawy indywidualizmu. Każda z plotek, których bohaterem jest tajemniczy brytyjski arystokrata, stanowi środek kontroli i władzy nad jednostka. Nasuwa się więc pytanie: co łączy plotkę $z$ ideami naturalizmu, scjentyzmu i autorytaryzmu?

Plotka - szczególnie opierająca się na osądach autorytetów społecznych i naukowych, takich jak francuski felietonista oraz niemiecki profesor - jest podstawowym narzędziem rozumu instrumentalnego ${ }^{32}$ :

dedukcyjna forma nauki odzwierciedla hierarchię i przymus. Tak jak pierwsze kategorie reprezentowały zorganizowane plemię i jego władzę nad jednostkami, tak cały porządek logiki, zależność, powiązanie, zawieranie się i łączenie pojęć ugruntowane są w odpowiednich stosunkach rzeczywistości społecznej, podziału pracy. Tyle że ów społeczny charakter form myślenia nie jest wyrazem społecznej solidarności - jak uczy Durkheim - ale świadectwem nierozerwalnej jedności społeczeństwa i panowania. Panowanie nadaje społecznej całości, w której zostaje ustanowione, większą spoistość i siłę. Podział pracy, który jest społecznym skutkiem panowania, pomaga przetrwać całości, która podlega panowaniu. Tym samym jednak całość jako całość, jako aktywność jej immanentnego rozumu, siłą rzeczy staje się egzekutorem partykularności. Panowanie występuje wobec jednostki jako to, co ogólne, jako urzeczywistniony rozum. [...] To, co spotyka wszystkich za sprawą niewielu, dokonuje się zawsze jako pokonywanie jednostki przez wielu: ucisk społeczeństwa nosi zawsze znamiona ucisku przez kolektyw ${ }^{33}$.

Lord poddany zostaje ocenie poprzez drobiazgową analizę jego poczynań, którą przeprowadza społeczeństwo przy użyciu narzędzi „rozumu instrumentalnego”.

32 Pojęcie rozumu instrumentalnego przejmuję od M. Horkheimera i Th. W. Ad orna (Dialektyka oświecenia. Fragmenty filozoficzne. Przeł. M. Łu k a s i e w i c z. Przekł. przejrzał i posł. opatrzył M. J. Si e mek. Warszawa 1994). 
Celem owej analizy nie jest poznanie prawdy o intencji aeronautycznych wypraw Singelwortha, lecz całkowite zdominowanie i podporzadkowanie sobie jednostki, która wymyka się kolektywizacji. Dlatego bohaterem swej noweli czyni Norwid przedstawiciela klasy wyższej. Jakkolwiek narrator ironizuje na poczatku utworu, zastanawiając się nad autentycznością nobilitacji aeronauty, pozostaje faktem, że dla „urzeczywistnionego rozumu” opinii publicznej należy on do arystokracji. I jako taki, jako relikt feudalnej przeszłości, nie włącza się w „społeczny podział pracy”. Nie jest więc członkiem kolektywu. Podstawowy cel rozumu instrumentalnego stanowi maksymalizacja produkcji masowej, a lord w niej nie uczestniczy. Jego manifest nie może zostać przyjęty przez opinię społeczną ,wieku kupieckiego i przemysłowego" (N-8 433), ponieważ nie przynosi zysku, którego efektem byłoby pomnożenie kapitału. Dla społeczeństwa, reprezentowanego przez jego ujarzmione elity intelektualne, postępowanie Lorda jest nieracjonalne:

Poprzez niezliczone agentury produkcji masowej i jej kultury unormowane zachowania wpajane sa jednostce jako jedyne naturalne, przyzwoite, rozumne. Człowiek określa się już tylko jako rzecz, jako element statyczny, jako success or failure ${ }^{34}$.

Tym należy tłumaczyć wszystkie wymienione interpretacje aktywności arystokraty. Zmierzaja one do opresyjnego wcielenia lorda do kolektywu społecznego, włączenia go do systemu produkcji. Jeżeli jego aeronautyczne podróże miałyby charakter użytkowy, postępowanie bohatera mogłoby być uznane przez społeczeństwo za rozumne i sensowne. Dzięki badaniom meteorologicznym lub fizjologicznym Singelworth dokonałby odkryć, które później podlegałyby urynkowieniu. Taką postawę, pracy wyzutej z jakiegokolwiek idealizmu, Norwid w liście z 1862 roku do Joanny Kuczyńskiej nazywał „p rzy zwo itym-Tytaństwe m”:

To albowiem, gdyby w dziejach ze wszech miar było podobieństwem - to jest, aby nic wiarą naprzód nie zdobywać - bylibyśmy nie ludźmi, ale bar d zo - pr zy z w o i t y m i - Ty t a n a mi. Jest to zaś, uważam, chorobą ukształcenia współczesnego, iż nieznany i nowy potwór, potwór p rzy zw o i t e go - Tytańs twa, za cel miewa. [N-9 48]

„Potwór przyzwoitego-Tytaństwa” odbiera cywilizacji idee, podporządkowując pracę celom doraźnym. Praca nie służy - jak wedle znanego Norwidowskiego aforyzmu - zbawieniu, lecz nieustannemu pomnażaniu kapitału, a społeczeństwo pozbawione idei przekształca się w zbiór zatomizowanych jednostek „funkcjonujących jako trybiki czy użyteczne narzędzia w mechanizmie społeczno-gospodarczym nastawionym wyłącznie na produkcję dóbr materialnych i robienie "wątpliwo-trwałych pieniędzy" "35.

Punktem zbieżnym między poglądami Norwida a refleksją reprezentantów szkoły frankfurckiej jest świadomość głębokich przemian, które nastapiły w kulturze drugiej połowy XIX wieku, a których główną (dla Adorna, Horkheimera, Benjamina) i istotną (dla Norwida) przyczynę stanowi rozwój gospodarki kapitalistycznej, opartej na paradygmacie liberalnym ${ }^{36}$. Co jednak w kontekście Tajemni-

E. Ka s per s ki, Świat wartości Norwida. Warszawa 1981, s. 18. 
cy lorda Singelworth wydaje się najistotniejsze, to Norwidowska refleksja, że mechanizmy wolnego rynku wpływają trwale nie tylko na kształt teraźniejszości, ale również - co też zauważają Adorno i Horkheimer - ingerują w obraz przeszłości i próbują go modelować, dekonstruować. Ten problem najostrzej i najdobitniej ukazał Norwid w noweli „Ad leones!”, w której artysta zmuszony jest zniszczyć swoją rzeźbę, przedstawiającą śmierć pierwszych chrześcijan, by na jej miejsce stworzyć tendencyjną alegorię - pomnik potęgi gospodarki rynkowej. W „Ad leones!”, a także wcześniej (np. w Pierścieniu Wielkiej-Damy) autor przedstawia zagadnienie wypierania idei przez kulturę materialną ${ }^{37}$. Mieczysław Inglot, analizujac Norwidowską koncepcję procesu historycznego, zauważał:

Określając zakres swoich historycznych zainteresowań mianem „cywilizacji”, dostrzegając w roli ziemskiego motoru historycznej zmienności „postęp” z jednej, a „tradycję" z drugiej strony, [Norwid] stale akcentował swoją niechęć do materialnych przejawów kultury ludzkiej, która to de facto determinowała w poważnym stopniu charakter przemian „wieku kupieckiego i przemysłowego” 38 .

Lord jako idealista - czemu dał wyraz w monologu w drugiej części noweli, skierowanym do przedstawicieli weneckich wyższych sfer - nie pasuje do realiów rodzącej się późnej nowoczesności. Ironiczny stosunek Norwida do arystokratyzmu Singelwortha wynika ze świadomości schyłku roli odgrywanej przez tę grupę społeczną w kulturze drugiej połowy XIX wieku. Obserwacja poety nie musiała wynikać tylko z oceny polskiej - skłóconej i politycznie anemicznej - arystokracji. Przebywając przez wiele lat w Paryżu (którego z czasem coraz bardziej nienawidził), czytając francuską prasę, obserwując życie społeczne, Norwid był świadkiem stopniowej przemiany arystokracji w mieszczaństwo. Komentując prozę Stendhala, René Girard pisał:

Arystokrata usiłuje zaznaczyć swoją inność właśnie dlatego, że przestał się wyróżniać. I zaznacza doskonale, tyle że tak czy inaczej nie przydaje mu to szlachectwa. [...] Arystokrata pragnie udowodnić Inny m, że „zasługuje” na przywileje [... ${ }^{39}$.

Przywilejem, na którym najbardziej zależało arystokracji w XIX wieku, było włączenie się do machiny wolnego rynku, co pozwoliłoby elicie krwi zachować i pomnażać topniejący kapitał. Kwintesencję tego szczęśliwie zrealizowanego marzenia stanowią słowa króla Ludwika Filipa: „Niech będzie pochwalony Pan Bóg

socjalistycznym. Jak wskazuje M. In gl ot (Norwidowska Europa. W zb.: Kategoria Europy w kulturach słowiańskich. Red. T. Dą b e k-Wirgowa, A. Z. Mak ow i e cki. Warszawa 1992, s. 66), w twórczości poety „Komuna Paryska, a następnie ruch rosyjskich nihilistów uznane zostały za wydarzenia zagrażające podstawom europejskiej tożsamości”. Sam siebie Norwid określał mianem „konserwatysty oświeconego” - człowieka wiernego tradycji, ale również gotowego do przenikliwej krytyki rzeczywistości go otaczającej. W jego twórczości publicystycznej (np. O emancypacji kobiet, Fabulizm Darwina) szczególnie widoczne sa jednak sprzeczność i oksymoroniczność tego określenia. Ten problem rozwijam w artykule Norwid nieznany. Śmierć Boga $w$ „Pierścieniu Wielkiej-Damy” Norwida („Acta Universitatis Lodziensis. Folia Litteraria Polonica” 2013, nr 4).

38 M. In glot, Koncepcja procesu historycznego $w$ listach Cypriana Norwida. W zb.: Norwid wobec historii, s. 54.

39 R. Girard, Prawda powieściowa i kłamstwo romantyczne. Przeł. K. Kot. Warszawa 2002, s. $130-131$. 
i moje sklepy" ${ }^{40}$. Singelworth to jednak inny typ arystokraty. Nawet jeżeli jego rodzice „byli zacnymi właścicielami rękodzielni wyrabiających perkaliki albo rzeczy cynowe i stalne" (N-6 147), a tytuł lorda jest dla niego tylko poręcznym pseudonimem, Singelworth jako skrajny idealista pozostaje arystokrata ducha. Jego nazwisko wyraża prawdziwą nobilitację i oddaje istotę jego tożsamości - lord, zamiast podporządkować się kolektywizacji, zachowuje indywidualizm, odgrywając rolę „uprzedziciela i zwiastuna Wielkiej Epoki nowej” (N-6 161).

\section{Singel-worth ${ }^{41}$}

Za główny cel swych balonowych podróży przyjął lord przywrócenie społeczeństwu świadomości tego, czym jest czystość:

Przyczyną główną codziennego używania aeronaucji jest moje pojęcie o czys tości. Celemjest czystość.

Szlachetni panowie i cała społeczność pojmujecie czystość jako za prze c ze ni e nieczy s to ści. Odpowiednia doza perfum gdy staje w przeciwieństwie względem dozy odpowiedniej rozkładowego fetoru, jest to dla was czystym oddechem, bo taki już macie nerwów ustrój. Pewien rodzaj dualizmu powonienia i aspiracji wyrobił się już wokoło was - i tak jest w ludziach, jak u niektórych pokoleń na Kaukazie: rozdwojenie na zło i d obro, pojęcia bóstwa! [N-6 158]

Manifest lorda ma dwa wymiary - aksjologiczny i etyczny. Misji arystokraty przyświeca cel: „odpowiednie dać rzeczy - słowo” (N-2 13), przywrócić pojęciu czystości niezależność semantyczną. Czystość nie jest więc zaprzeczeniem nieczystości, a dobro - tylko negacją zła. Dążenie do autonomii idei czystości wiąże się również ze świadomością konsekwencji - nieustannej, społecznej kampanii tępienia brudu:

Prawdą jest to, że te i owe municypalności walczą mężnie, lecz ażeby usunąć nieco falangę kału, muszą one całą falangę ludzi zdegradować, zmieniając ich w bryły bez powonienia i bez towarzyskiego wdzięku, i z którymi do stołu siąść nikt nie chce... [N-6 159]

W rzeczywistości otaczającej lorda starania o uzyskanie i zachowanie stanu czystości doprowadzają do degradacji i stygmatyzacji jednostek odpowiedzialnych za zapewnienie porządku. Europa bowiem okazuje się przestrzenią brudu, który - z powodu mylnych przekonań aksjologicznych - może tylko zostać przykryty, „uperfumowany”. Stykający się z nim ludzie podlegają podobnemu społecznemu wykluczeniu jak hinduscy pariasi, których zadaniem jest palenie odpadków i zwłok - stają się nieczyści. Gdyby walka z nieładem przywracała czystość na wzór chrześcijańskiej apokatastazy, wypełniający tę szczytną misję byliby najbardziej szanowanymi członkami społeczeństwa: „Czystość, która musiałaby degradować ludzi, ażeby siebie utrzymać, byłażby bez-plamną?” (N-6 160).

Podstawowe zadanie lorda polega więc na przypomnieniu znaczenia idei czystości przez jej ekspozycję, a nie negację. Dlatego bohater wybiera lot balonem.

40 W. Benjamin, Pasaże. Red. R. Tie demann. Przeł. I. Kania. Posł. Z. Ba uman. Kraków 2005, s. 70 .

41 Nazwisko znaczące: „single” - ang. 'pojedynczy', 'osobny', 'jednolity'; „worth” - ang. 'wartość', 'cena'. Zob. Dąbrowicz, op. cit., s. 218 (przypis). 
W sferze, do której wznosi się Singelworth w balonowym koszu, „n i e c zy s t o ś c i wcale nie ma!... Tam ciagły p or zą d e k jest i pełni się, w ustawach sił, warunków atmosfery założonym będąc" (N-6 160). Tym samym Singelworth - co zauważył w ostatnim monologu Tony di Bona Grazia - to „uprzedziciel i zwiastun Wielkiej Epoki nowej, która ma stać się dla ludzkości całej rodzajem puryfikacji i czymś do Revivalu amerykańskiego podobnym" (N-6 161).

\section{Karnawał}

Wenecki improwizator to jedyny z komentatorów poprawnie rozszyfrowujący tajemnicę aeronautycznej pasji Singelwortha. Pojawia się więc pytanie: jak bardzo teza o dialogu z przeszłością, który prowadzi zawieszony ponad miastami lord, łączy się $\mathrm{z}$ manifestem odrodzenia aksjologicznego?

Gdy narrator wspomina o „despotyzmie rządu obcego” (N-6 149), niewolącym wenecjan, zauważa:

Wenecja, nazbyt będąc oryginalną, ażeby mogła być ostatecznie ujarzmioną, pozostawała tym samym dziwnym miastem.

Miastem w posadach swoich mającym pierwszowieczną lakustralną konstrukcję na palach; potem targiem-rybaków i uskoków schronieniem; potem jeszcze miastem kramarzących z fenicka przedsiębierców, związanych nareszcie w Republikę bynajmniej spartańską, ale owszem noszącą bisior szeroki, który leniwo wlókł się za złotym jej sandałem, nieco na azjacki lub wschodni sposób szpiczastym i w górę podkrzywionym. [N-6 151-152]

Tożsamość mieszkańców Wenecji - miasta ufundowanego na wielowiekowej historii - nie pozwala im poddać się jarzmu władz okupanta. Kwintesencję owej tożsamości stanowi cyklicznie powtarzane święto karnawału:

Lecz Wenecja ma misję świadczenia człowiekowi, że jest fantastyczna sfera życia, że stolica nie jest tylko samym z-centralizowaniem administracyjnym kilku biur - że plac może być salonem, bo to zależy od przechodniów i onychże obyczajności - że na kościele katolickim może igrać cztery brazowe konie rydwanu Apollinowego, nic nabożeństwu nie szkodząc... I że przeto śmiertelny na tym świecie nie jest tylko rodzajem nadkompletowego urzędnika, pełniącego o swoich godzinach własne albo cudze interesa, ale że i godność żywego członka bytu we wszech-stworzeniu on ma, a przez to samo może się i zadumać, i za-rozmawiać i zabawić!.. [N-6 156-157]

Wenecja okazuje się theatrum mundi, a karnawał - metafora ludzkiego życia. Życia, w którym piękno przeplata się z brzydotą, przeszłość z teraźniejszością, smutek $\mathrm{z}$ radością. Teatralność i manieryzm cechujące zarówno wypowiedź Tony’ego di Bona Grazii, jak i słowa narratora wprowadzają czytelnika w przestrzeń maskarady i karnawału, gdzie celem -

nie jest prosta antyteza codzienności, lecz taki obraz świata, w którym karnawał i post współgraja ze sobą. Dlatego właśnie są one sobie wzajemnie potrzebne, nie mogą istnieć w oderwaniu od siebie. Tylko jako dwa bieguny tego świata, w którym żyjemy, mogą wskazywać na jakiś świat wyższy, istniejący poza przeciwstawieniem tych dwóch realności ${ }^{42}$. 
Podczas karnawału obnażona zostaje teatralność rzeczywistości społecznej. Gdy opadnie kurtyna, człowiek może na chwile poczuć się naprawdę wolny. Karnawał staje się ceremonią, świętem totalnym, które -

[umożliwia] świętującym pozorne „wyjście z czasu”, znalezienie się „poza czasem”, potem zaś powrót do niego bez konsekwencji upływu „zatrzymanych” dni i utraty czegokolwiek, co mogłoby się zdarzyć i wszystko jest nagle inne: porządek zmienia się w nieporządek, harmonia w dysonans, umiar w nadmiar, powaga w śmiech, prawo w bezprawie, a sacrum w profanum ${ }^{43}$.

Stan wolności nie jest jednak tylko chwilowy. Jak stwierdził Norwid w przywołanym wcześniej fragmencie noweli, wenecki karnawał pozwala odnaleźć wytchnienie w steatralizowanej, skonwencjonalizowanej rzeczywistości. Tragizm weneckich samobójców bierze się bowiem stąd, że przyszło im żyć „w świecie pozbawionym nagle złudzeń”, w którym „człowiek czuje się obcy”:

To wygnanie jest nieodwołalne, skoro braknie wspomnienia utraconej ojczyzny albo nadziei na ziemię obiecaną. Ta niezgodność pomiędzy człowiekiem a jego życiem, pomiędzy aktorem a dekoracją, jest właśnie poczuciem absurdu ${ }^{44}$.

Poczucie niezgodności między aktorem a dekoracją stanowi fundament Norwidowskiej ironii losu, będącej - jak zauważył Sławomir Świontek -,wynikiem starcia "woli« i "historii»" 45 . Karnawał polega jednak nie tyle na „wyjściu z czasu”, zignorowaniu historii, ile na zagłębieniu się w niej, na cyklicznym, ciągle na przestrzeni wieków powtarzanym odwracaniu świata na opak. Zakorzeniona w pamięci zbiorowej tradycja, kultywowanie zwyczajów przodków, rozsadzaja skostniałą teraźniejszość. Negując konwencje społeczne ceremonia przywraca istniejacy w zbiorowej świadomości mit o niegdysiejszym egalitaryzmie i o wspólnocie. Karnawał okazuje się więc - poprzez „uobecnienie przeszłości fundacyjnej” - manifestacją marzenia o ponownym włączeniu się człowieka w historię:

Przykłady pokazują, że w pamięci kulturowej obecny jest pewien element sakralny. Figury pamięci posiadają sens religijny, a uobecnianie ich przez wspominanie ma często charakter święta. Święto - obok licznych innych funkcji - służy uobecnieniu przeszłości fundacyjnej. Przez odniesienie do przeszłości ustanowiona zostaje tożsamość wspominającej grupy. Wspominając swoją historię i przywołując figury pamięci, grupy społeczne upewniają się co do swojej tożsamości ${ }^{46}$.

Jak twierdzi Norwid w Rzeczy o wolności słowa, istota ewolucji dziejów jest nieustanny proces wcielania słowa (idei) w życie pojedynczego człowieka i społeczeństwa. Wolność jednostki sprzęga się z wolnością idei (słowa); walka o autonomię czystości to batalia o niezależność człowieka. Stąd bierze się aeronautyczny protest lorda przeciwko błędnemu definiowaniu wartości. Cel arystokraty stanowi bowiem włączenie człowieka w historię poprzez ponowne wcielenie słowa-idei w rzeczywistość społeczna.

W. Dudzik, Karnawaty $w$ kulturze. Warszawa 2005, s. 44.

A. C a mu s, Mit Syzyfa. W: Eseje. Wstęp J. Kossak. Wybór, przekł., przypisy J. Guze. Wyd. 2. Warszawa 1974, s. 99.

S. Świ o n tek, Norwidowski teatr świata. Łódź 1983, s. 134.

As sman n, op. cit., s. 68. 
Człowiek, będący częścią „Dziejów-zaciagu”” (N-2 106), odzyskuje utraconą godność, tak jak odzyskują ją weneccy samobójcy, których biografie stały się trwałym elementem wielkiej historii i wynikającego z niej piękna weneckich zabytków. Imperatyw pamięci zmusza do dialogu $z$ przeszłością. Przywraca zatem godność tym, których nieludzki pragmatyzm rzeczywistości, opartej na tym, co chwilowe i doraźne, niszczy i skazuje na zapomnienie. Norwid, tworząc w Tajemnicy lorda Singelworth metafory przestrzenne, łączy dwie perspektywy: sferę życia społecznego (,warunki poziome”) ze sferą historii, która reprezentują wertykalny manifest lorda oraz historyczna architektura miasta, składającą się $\mathrm{z}$,gotyckich wież, łuków triumfalnych i kolumn" (N-6 150). Nałożenie topografii pamięci na mape Wenecji formuje kształt krzyża:

Parabola „krzyża” dziejów w przedziwny sposób harmonizuje doświadczane przez człowieka antynomie, zachodzące między wolą Boga i wolnością człowieka, rytmiką historii świętej i świeckiej, między ofiarą i historycznym postępem, wskazując ciaggle na paschalny horyzont ludzkiej historii ${ }^{47}$.

Rozwiązanie tajemnicy brytyjskiego lorda stanowi więc emancypacja człowieka: jego podmiotowość, wolność, poprzez nadanie jego życiu szerszej perspektywy niż ta, jaką rozwój gospodarki rynkowej i przemysłu kulturowego był w stanie mu zaproponować. Społeczny „rozum instrumentalny” zostaje zastapiony w Tajemnicy lorda Singelworth topografią pamięci, której sens najdobitniej wyraża znany Norwidowski aforyzm „Przeszłość - jest to dziś, tylko cokolwiek daléj” (N-2 18).

\author{
Abstract \\ MATEUSZ GRABOWSKI University of Łódź
}

\title{
TOPOGRAPHY OF MEMORY IN NORWID'S “TAJEMNICA LORDA SINGELWORTH” (“LORD SINGELWORTH'S SECRET")
}

The aim of the article is to reflect on the relationship between past and present in Cyprian Norwid's Tajemnica lorda Singelworth (Lord Singelworth's Secret), since the character from the novella's title travels in a space marked by great history of the Republic of Venice. In this respect, Norwid gives on the topography of the city sightseen by the character the topography of memory. This memory brings back not only political history, but first and foremost the biographies of individuals crashed by the mechanisms of late modernity. Reflection on the role of history and memory in the reality of European social life in the second half of $19^{\text {th }}$ century allows to picture the image of arising modernity - the process of Haussmannisation - criticised by Norwid, in its late phase. 